\title{
Histamine dose-response curves in asthma: reproducibility and sensitivity of different indices to assess response
}

\author{
P DEHAUT, A RACHIELE, RR MARTIN, JL MALO
}

\section{From the Department of Chest Medicine, Hôpital du Sacré-Coeur, Montreal, Canada}

ABSTRACT In 18 clinically stable asthmatic patients histamine inhalation challenges were performed with a Wright's nebuliser and tidal volume breathing for two minutes on two to four occasions for each subject at a maximum interval of two weeks. The response was measured in terms of specific lung conductance (sGL) by the subtraction technique, maximum partial and maximum complete expiratory flow at $40 \%$ and $50 \%$ of vital capacity respectively $\left(\operatorname{Vmax}_{40 \mathrm{p}}\right.$ and $\dot{V} \max _{\text {soc }}$ ), and $\mathrm{FEV}_{1}$ from the maximum flow-volume curve. Dose-response curves were analysed for (1) provocative concentration (PC) of histamine causing a $20 \%$ fall in $\mathrm{FEV}_{1}$ and a $40 \%$ change in the other measurements; (2) threshold concentration (TC)-the concentration at which changes in the measurement exceed 2 SD from control values; (3) reactivity (R)-the slope of the dose-response curve beyond TC. We found that $\mathrm{PC}_{20} \mathrm{FEv}_{1}$ was the most reproducible index, the $95 \%$ confidence intervals based on a single determination being \pm 1.6 single two-fold concentration difference. $\mathrm{PC}_{20} \mathrm{FEV}_{1}$ was more reproducible than $\mathrm{PC}$ values for other measurements and more reproducible than any of the TC values. The $95 \%$ confidence intervals based on a single determination of $\mathrm{R}$ varied from $\because 52 \%$ to $\pm 74 \%$ change/log histamine concentration. Both $\mathrm{sGL}$ and $\dot{\mathrm{V}} \mathrm{max}_{40 \mathrm{p}}$ detected the bronchoconstrictor response assessed by PC and TC at a significantly lower histamine concentration than $\mathrm{FEV}_{1}(\mathrm{p}<0.01$ and $\mathrm{p}<0.05$ respectively). PC and TC results showed a significant correlation, but neither were correlated with R.

After Dautrebande and Philippot ${ }^{1}$ introduced nonallergic bronchial inhalation challenges in 1941, Tiffeneau, ${ }^{2}$ Curry, ${ }^{3}$ and De Vries ${ }^{4}$ used the tests for clinical purposes. Attempts to standardise the procedure have been made, ${ }^{56}$ but so far only a few studies of reproducibility have been published..$^{7-9}$ In these studies the forced expiratory volume in one second $\left(F E V_{1}\right)$ only was used to monitor response, and the dose-response curve was assessed by only one index, either the threshold concentration (TC) or the provocative concentration (PC) of the stimulus causing a predetermined fall in $\mathrm{FEV}_{1}$. We decided to study histamine dose-response curves in clinically stable asthmatic subjects to assess the reproducibility and sensitivity of different measurements of bronchoconstriction, using different indices from the dose-response curves. Address for reprint requests: Dr JL Malo, Department of Chest
Medicine, Hopital du Sacre-Coeur, 5400W Gouin, Montreal,
Canada H4J 1C5.

Accepted 16 February 1983

\section{Methods}

PATIENTS

We studied 18 patients (five male, thirteen female) aged 19-55 years (table 1). All satisfied the criteria for asthma of the American Thoracic Society ${ }^{10}$ and were clinically stable at the time of study, with no nocturnal awakening due to asthma and minimum symptoms by day. None of the subjects reported any respiratory infection in the six weeks preceding the test. Patients with immediate positive skin reactions to animal dander and pollen had had no exposure to these allergens in the month preceding the study. At the time of study all subjects were taking bronchodilator medication on a regular basis or less frequently, and 12 were taking inhaled beclomethasone regularly. Bronchodilators were withheld before the inhalation tests for the time interval suggested by the special committee of the American Academy of Allergy. ${ }^{5}$ Written consent was obtained from each subject and the project was accepted by the local ethical committee. 
Table 1 Baseline anthropometric, functional, and clinical data

\begin{tabular}{|c|c|c|c|c|c|c|c|c|c|}
\hline \multirow[t]{2}{*}{ No } & \multirow[t]{2}{*}{ Sex } & \multirow{2}{*}{$\begin{array}{l}\text { Age } \\
\text { (y) }\end{array}$} & \multirow{2}{*}{$\begin{array}{l}\text { Height } \\
(\mathrm{cm})\end{array}$} & \multirow{2}{*}{$\underset{\left(s^{-1} k P a^{-1}\right)}{s G L}$} & \multicolumn{2}{|c|}{$F E V_{1}$} & \multicolumn{2}{|c|}{$\dot{V}_{\max }{ }_{s o c}$} & \multirow[t]{2}{*}{ Medication } \\
\hline & & & & & $\begin{array}{l}\text { Obs } \\
\text { (l) }\end{array}$ & $\% p$ & $\underset{\left(1 s^{-1}\right)}{O b s}$ & $\% p$ & \\
\hline $\begin{array}{r}1 \\
2 \\
3 \\
4 \\
5 \\
6 \\
7 \\
8 \\
9 \\
10 \\
11 \\
12 \\
13 \\
14 \\
15 \\
16 \\
17 \\
18\end{array}$ & $\begin{array}{l}\mathbf{M} \\
\mathbf{F} \\
\mathbf{M} \\
\mathbf{F} \\
\mathbf{F} \\
\mathbf{F} \\
\mathbf{F} \\
\mathbf{M} \\
\mathbf{F} \\
\mathbf{F} \\
\mathbf{F} \\
\mathbf{M} \\
\mathbf{F} \\
\mathbf{F} \\
\mathbf{F} \\
\mathbf{F} \\
\mathbf{M} \\
\mathbf{F}\end{array}$ & $\begin{array}{l}48 \\
42 \\
25 \\
32 \\
33 \\
38 \\
23 \\
28 \\
19 \\
39 \\
55 \\
21 \\
26 \\
38 \\
49 \\
52 \\
39 \\
48\end{array}$ & $\begin{array}{l}180 \\
158 \\
158 \\
165 \\
158 \\
165 \\
155 \\
180 \\
168 \\
161 \\
157 \\
170 \\
168 \\
170 \\
160 \\
155 \\
180 \\
161\end{array}$ & $\begin{array}{l}0.80 \\
2.09 \\
2.50 \\
1.08 \\
2.37 \\
1.27 \\
0.79 \\
0.50 \\
2.55 \\
1.06 \\
1.55 \\
1.02 \\
1.65 \\
1.05 \\
1.01 \\
1.16 \\
0.44 \\
1.31\end{array}$ & $\begin{array}{l}3.2 \\
3.5 \\
3.8 \\
2.4 \\
2.7 \\
3.0 \\
2.4 \\
3.4 \\
3.2 \\
2.6 \\
2.2 \\
2.5 \\
3.0 \\
2.9 \\
2.2 \\
1.6 \\
2.3 \\
2.3\end{array}$ & $\begin{array}{r}89 \\
140 \\
104 \\
86 \\
104 \\
115 \\
89 \\
81 \\
93 \\
104 \\
116 \\
62 \\
101 \\
107 \\
99 \\
82 \\
60 \\
106\end{array}$ & $\begin{array}{l}5.7 \\
3.7 \\
4.6 \\
5.1 \\
3.8 \\
4.3 \\
4.0 \\
4.7 \\
4.0 \\
3.0 \\
4.0 \\
2.0 \\
2.4 \\
3.4 \\
3.1 \\
1.9 \\
1.6 \\
2.4\end{array}$ & $\begin{array}{r}105 \\
80 \\
74 \\
104 \\
79 \\
91 \\
80 \\
77 \\
74 \\
66 \\
94 \\
33 \\
45 \\
71 \\
70 \\
43 \\
27 \\
53\end{array}$ & $\begin{array}{l}\text { B; BDT reg } \\
\text { B; BDT reg } \\
\text { B; BDT reg } \\
\text { BDT reg } \\
\text { BDT reg } \\
\text { B; BDT reg } \\
\text { BDT prn } \\
\text { B; BDT reg } \\
\text { BDT prn } \\
\text { B; BDT reg } \\
\text { B; BDT reg } \\
\text { B; BDT reg } \\
\text { B; BDT reg } \\
\text { BDT prn } \\
\text { B; BDT reg } \\
\text { B; BDT reg } \\
\text { B; BDT reg } \\
\text { B; BDT reg }\end{array}$ \\
\hline $\begin{array}{l}\text { Mean } \\
\text { SD }\end{array}$ & - & $\begin{array}{l}36 \cdot 4 \\
11 \cdot 2\end{array}$ & $\begin{array}{r}164.9 \\
8.4\end{array}$ & $\begin{array}{l}1 \cdot 34 \\
0.65\end{array}$ & $\begin{array}{l}2.7 \\
0.6\end{array}$ & $\begin{array}{l}96 \cdot 6 \\
19 \cdot 1\end{array}$ & $\begin{array}{l}3 \cdot 5 \\
1 \cdot 2\end{array}$ & $\begin{array}{l}70 \cdot 3 \\
22 \cdot 5\end{array}$ & \\
\hline
\end{tabular}

sGL-specific lung conductance; $\dot{V} \max _{\text {soc }}$-maximum complete expiratory flow rate at $50 \%$ vital capacity; $\%$ p- $\%$ predicted values for FEV ${ }_{1}{ }^{\bullet}$ and $\dot{V}$ max ${ }_{\text {soc }}{ }^{17}$, BDT - bronchodilator ( $\beta_{2}$-adrenergic agents or xanthine preparations or both); B-beclomethasone inhaler; reg-regularly (two or four times daily); prn-only if needed.

\section{MEASUREMENTS}

All measurements were made in a flowdisplacement body plethysmograph as described by Leith and Mead." After pressure compensation of the integrated flow signal, the volume signal was flat $( \pm 5 \%)$ to 12 cycles $\mathrm{s}^{-1}$. Lung resistance (RL) was calculated by the subtraction technique described by Mead and Whittenberger ${ }^{12}$ and lung volume by using Boyle's law. Flow at the mouth was measured with a No 4 Fleisch pneumotachograph connected to a Validyne pressure transducer. The flow signal was electrically integrated to derive volume, from which FEV, was calculated. Pleural pressure was estimated from an oesophageal balloon ${ }^{13} 10 \mathrm{~cm}$ long connected to a Validyne differential pressure transducer via a $100-\mathrm{cm}$ polyethylene catheter. The other side of the transducer was connected to an oral pressure tap to give transpulmonary pressure. $\mathrm{RL}$ was measured as the ratio of change in transpulmonary pressure to change in mouth flow during tidal breathing.

Partial flow-volume curves were initiated from residual volume. Partial and complete maximum expiratory flow-volume curves were drawn on a Hewlett-Packard X-Y recorder. Maximum flow from the partial and complete flow-volume curves was measured at $40 \%\left(\dot{V}_{\max }{ }_{40 p}\right)$ and $50 \%$ $\left(\dot{V}_{\text {max }}{ }_{\text {soc }}\right)$ of the forced vital capacity (FVC) respectively. When FVC changed by more than $5 \%$ a correction was made for total lung capacity as proposed by Habib et al. ${ }^{14}$ When changes in TLC were $10 \%$ or less maximum expiratory flow-volume curves were matched at TLC. A volume equivalent to $60 \%$ of control FVC was subtracted from TLC and flow rates at this volume were obtained from the partial flow-volume curve. A similar procedure was used to determine flows at $50 \%$ of FVC from the complete flow-volume curve. When TLC changes were more than $10 \%$ the results were discarded.

Reference values were taken from Goldman and Becklake $^{15}$ and from Cherniack ${ }^{16}$ for FEV, and $\dot{V} \max _{\text {soc }}$ respectively.

\section{STUDY DESIGN}

Subjects were studied on two (10 subjects), three (one subject), or four (seven subjects) occasions, at the same time of day on separate days, with a maximum interval between studies of two weeks. Baseline measurements of $R L$ and thoracic gas volume (TGV) were carried out to derive specific lung conductance (sGL), and partial and complete maximum expiratory flow-volume curves were then produced. Subjects then inhaled phosphate buffer saline from a Wright's nebuliser (output $0.15 \mathrm{ml}$ min) through a face mask for two minutes, ${ }^{6-8}$ breathing tidally at a rate of 14 breaths a minute in time with a metronome. $R L$ and TGV were measured one to two minutes after the end of nebulisation. The subject then performed two maximum partial expiratory manoeuvres, initiated from the endinspiratory position. These were followed immediately by two complete forced expiratory manoeuvres 
initiated from TLC. All measurements were completed within three minutes of the end of nebulisation. This interval is within the period of the maximum bronchoconstrictor effect of histamine, which has been estimated to last for a mean of 16.8 minutes (range 4-37 $\mathrm{min}$ ). ${ }^{17}$ Two inhalations of diluent were followed by increasing concentrations of histamine, from 0.03 to a maximum dose of $32 \mathrm{mg} / \mathrm{ml}$. The histamine was given at five-minute intervals to prevent any cumulative effect of histamine. ${ }^{7}$ The test was stopped when the patient showed a $30-50 \%$ fall in $\mathrm{FEV}_{1}$.

\section{ANALYSIS OF DOSE-RESPONSE CURVES}

Dose-response curves were drawn on a semi-log scale, the abscissa representing the concentration and the ordinate the percentage change in each measurement. The following indices were obtained from each dose-response curve: (1) TC-the concentration of histamine which produced a change in excess of 2 SD from mean post-diluent values (four post-diluent values for $\mathrm{FEV}_{1}$ and maximum flows and 10 post-diluent values for $\mathrm{sGL}$ ): for the 10 subjects who made only two visits there were insufficient measurements to calculate $\mathrm{TC}$ for $\mathrm{SGL}$; (2) PC - the concentration of histamine causing a predetermined fall in each measurement, $20 \%$ for $\mathrm{FEV}_{1}\left(\mathrm{PC}_{20}\right)$ and $40 \%$ for the other measurements $\left(\mathrm{PC}_{40}\right)$. These percentages were well outside the range of measurements seen after inhalation of diluent (table 2); (3) reactivity (R)-the slope of the
Table 2 Reproducibility of post-diluent assessments

\begin{tabular}{lllll}
\hline & $F E V_{1}$ & $s G L$ & $\dot{V} \max _{4 \varphi p}$ & $\dot{V}_{\max }{ }_{s 0}$ \\
\hline $\begin{array}{l}\text { Coefficient of } \\
\text { variation (\%): }\end{array}$ & & & & \\
Mean & $2 \cdot 6$ & $10 \cdot 0$ & $8 \cdot 2$ & $5 \cdot 5$ \\
SD & $1 \cdot 2$ & $3 \cdot 1$ & $3 \cdot 8$ & $3 \cdot 2$ \\
Range & $0-5 \cdot 3$ & $2 \cdot 8-16 \cdot 2$ & $2 \cdot 9-15 \cdot 8$ & $0-15 \cdot 3$ \\
\hline
\end{tabular}

Individual coefficients of variation obtained at each visit from four post-diluent measurements of FEV,$V_{\max }$ and $V_{\max }$ and 10 measurements of sGL ( 51 assessments in 18 subjects for each measurement except sGL, for which there were 31 measurements in eight subjects. Abbreviations as in table 1.

dose-response curve beyond TC, including at least three points for each curve. For the 10 subjects for whom TC sGL could not be obtained $\mathrm{R}$ was calculted from points in excess of a $30 \%$ fall in sGL. This is close to the upper limit of values for sGL in other subjects after inhalation of diluent (that is, twice the coefficient of variation) (table 3 ). The slope of the dose-response curve was calculated by the method of least squares, in keeping with previous studies of $\mathrm{FEV}_{1},{ }^{18}{ }^{19}$ specific airway conductance, ${ }^{2021}$ and maximum expiratory flows. ${ }^{14}$ Curves were retained for analysis only if $\mathrm{p}<0 \cdot 05$. Slope $a$ from the formula $y=a x+b$ was used to characterise reactivity.

\section{STATISTICAL MEASUREMENTS}

A one-way analysis of variance was used to compare within-subject and between-subject variance for log $\mathrm{TC}, \log \mathrm{PC}$, and $\mathrm{R}$, calculating intraclass correlation

Table 3 Reproducibility of dose-response curves: results from one-way analysis of variance

\begin{tabular}{|c|c|c|c|c|}
\hline Functional index & $F$ & IC correlation* & $95 \%$ CI overall mean* & $95 \%$ CI single determination ${ }^{*}$ \\
\hline \multicolumn{5}{|l|}{$\begin{array}{l}\text { Provocative } \\
\text { concentration }(P C)\end{array}$} \\
\hline $\begin{array}{l}\mathrm{PC}_{20}-\mathrm{FEV}_{1} \\
\mathrm{PC}\end{array}$ & $23 \cdot 5 \dagger$ & $0 \cdot 88$ & \pm 0.72 & $\pm 1 \cdot 59$ \\
\hline 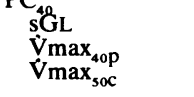 & $\begin{array}{l}13 \cdot 4^{\dagger} \\
12 \cdot 3{ }^{\dagger} \\
15 \cdot 5^{\dagger}\end{array}$ & $\begin{array}{l}0 \cdot 81 \\
0 \cdot 80 \\
0 \cdot 84\end{array}$ & $\begin{array}{l} \pm 1.00 \\
\pm 0.81 \\
\pm 0.76\end{array}$ & $\begin{array}{l} \pm 2.14 \\
\pm 1.83 \\
\pm 1.71\end{array}$ \\
\hline \multicolumn{5}{|l|}{$\begin{array}{l}\text { Threshold } \\
\text { concentration }(T C) \\
\text { TC }\end{array}$} \\
\hline $\begin{array}{l}\text { FEV } \\
\text { sGL } \\
\dot{V}_{\max } \\
\operatorname{Vmax}_{50 \mathrm{op}}\end{array}$ & $\begin{array}{r}11 \cdot 6 \dagger \\
22 \cdot 1 \dagger \\
4.6 \dagger \\
6 \cdot 7^{\dagger}\end{array}$ & $\begin{array}{l}0.79 \\
0.85 \\
0.57 \\
0.67\end{array}$ & $\begin{array}{l} \pm 0.85 \\
\pm 2.10 \\
\pm 1.65 \\
\pm 1.45\end{array}$ & $\begin{array}{l} \pm 1 \cdot 70 \\
\pm 2.24 \\
\pm 1.92 \\
\pm 1.74\end{array}$ \\
\hline \multicolumn{5}{|l|}{ Reactivity $(R)$} \\
\hline $\begin{array}{l}\text { FEV } \\
\text { sGL } \\
\bigcup_{\text {Vmax }} \max _{\text {oop }}\end{array}$ & $\begin{array}{c}11.4 \dagger \\
9.2 \dagger \\
2.7 \ddagger \\
5.4 \dagger\end{array}$ & $\begin{array}{l}0.79 \\
0.76 \\
0.38 \\
0.62\end{array}$ & $\begin{array}{l} \pm 12 \\
\pm 16 \\
\pm 14 \\
\pm 15\end{array}$ & $\begin{array}{l} \pm 52 \\
\pm 60 \\
\pm 74 \\
\pm 71\end{array}$ \\
\hline
\end{tabular}


Table 4 Comparison between the use of provocative concentration $(P C)$, threshold concentration $(T C)$, and reactivity $(R)$ : correlation coefficients ( $r$ ) for paired indices (21-51 assessments for each comparison)

\begin{tabular}{|c|c|c|c|c|c|c|c|c|c|c|c|c|}
\hline $\begin{array}{l}\mathrm{PC}_{20-\mathrm{FEV}_{1}} \\
\mathrm{PC}_{40} \\
\mathrm{sGL}^{\mathrm{SG}} \\
\mathrm{Vmax}^{40 \mathrm{p}} \\
\mathrm{Vmaax}_{\text {soc }}\end{array}$ & $\begin{array}{l}* \\
=\end{array}$ & $\begin{array}{l}0.82 \dagger \\
= \\
=\end{array}$ & $\begin{array}{l}0.73 \dagger \\
0.84 \dagger \\
-\end{array}$ & $\begin{array}{l}0.81 \dagger \\
0.91 \dagger \\
0.95 \dagger\end{array}$ & & & & & & & & \\
\hline $\begin{array}{l}\text { TC } \\
\text { FEV } \\
\text { SGL } \\
\operatorname{Vmax}_{\text {4op }} \\
\operatorname{Vmax}_{\text {soc }}\end{array}$ & $\begin{array}{l}0.87 \dagger \\
=\end{array}$ & $\begin{array}{l}\overline{0.91 \dagger} \\
=\end{array}$ & $\overline{\bar{z}}$ & $\begin{array}{l}\bar{z} \\
\overline{0.63 \dagger}\end{array}$ & $\begin{array}{l}{ }^{*} \\
=\end{array}$ & $\begin{array}{l}0.79 \dagger \\
=\end{array}$ & $\begin{array}{l}0.75 \dagger \\
0.53 \dagger \\
- \\
-\end{array}$ & $\begin{array}{l}0.73 \dagger \\
0.79 \dagger \\
0.61 \dagger \\
*\end{array}$ & & & & \\
\hline $\begin{array}{l}R_{\text {FEV }} \\
\text { sGL } \\
\text { Vmax }_{\text {4op }} \\
\text { Vmax }_{\text {soc }}\end{array}$ & $\begin{array}{l}\frac{0 \cdot 16}{=} \\
=\end{array}$ & $\begin{array}{l}\overrightarrow{0.21} \\
-\end{array}$ & $\overline{\bar{z}}$ & $\begin{array}{l}\overline{\bar{z}} \\
0.08\end{array}$ & $\begin{array}{l}0.22 \\
=\end{array}$ & $\begin{array}{l}\overline{0.23} \\
\overline{-}\end{array}$ & $\begin{array}{l}\overline{\overline{0}} \\
-\end{array}$ & $\begin{array}{l}\bar{z} \\
0.24\end{array}$ & = & $\begin{array}{l}0.308 \\
= \\
=\end{array}$ & $\begin{array}{l}0.348 \\
0.90 \\
-\end{array}$ & $\begin{array}{l}0.30 \$ \\
0.74 \dagger \\
0.46 \ddagger \\
*\end{array}$ \\
\hline & 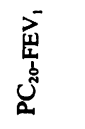 & نేّ & 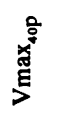 & 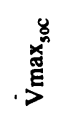 & 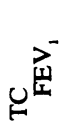 & $\overrightarrow{~ J ్ ~}$ & 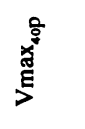 & 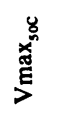 & 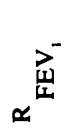 & $\vec{D}$ & . & 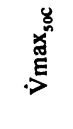 \\
\hline
\end{tabular}

* Results of one-way analysis of variance given in table 3 .

$\dagger \mathrm{p}<0.001 ; \ddagger \mathrm{p}<0.01 ; \S \mathrm{p}<0.05$; for other values $\mathrm{p}>0.05$.

as between-subject variance/total variance. The $95 \%$ confidence interval for the overal mean over subjects (that is, the $95 \%$ confidence interval of the mean for all subjects) and the range for subjects based on a single determination (that is, the $95 \%$ confidence interval for which a single value sampled at random would belong to the population) were calculated. ${ }^{8}$ Log TC and $\log$ PC results for each measurement were compared by analysis of variance.

Linear regression analysis was used to compare $\log \mathrm{TC}, \log \mathrm{PC}$, and $\mathrm{R}$ at each visit.

\section{Results}

\section{BASELINE FUNCTIONAL RESULTS}

On the initial assessment 14 subjects had an FEV, above $80 \%$ of the predicted value, while only four had a $\dot{V}_{\text {max }}$ soc above $80 \%$ predicted. The difference in $\mathrm{FEV}_{1}$ between assessments was within $10 \%$ for each subject; differences in $\mathrm{SGL}, \dot{\mathrm{V}} \mathrm{max}_{50 c}$, and $\dot{\mathrm{V}} \max _{40 \mathrm{p}}$ were within $50 \%$.

\section{REPRODUCIBILITY OF DOSE-RESPONSE CURVES}

The results for reproducibility derived from the one-way analysis of variance are listed in table 3 . The $F$ value and intraclass correlation show that between-subject variance was always larger than within-subject variance. The values of intraclass correlation (that is, the proportion of total variance due to real subject differences as opposed to measurement error) were satisfactory. Results of the $95 \%$ confidence interval for the overall mean over subjects and of the $95 \%$ confidence interval for subjects based on a single determination are also given in table 3. These results are expressed as single twofold concentration differences since doubling concentrations of histamine were nebulised (see under "Methods"). The 95\% confidence interval of $\mathrm{PC}_{20-\mathrm{FEV}_{1}}$ based on a single determination was the observed value \pm 1.59 two-fold concentration difference (that is, $\pm 3 \cdot 18$-fold difference). The range for $\mathrm{PC}_{20}$ for $\mathrm{FEV}_{1}$ was smaller than the ranges obtained for PC with other measurements. The confidence intervals for PC were smaller than those obtained for TC. The $95 \%$ confidence intervals of $R$ based on a single determination were the observed values $\pm 52- \pm 74$ (\% change/log histamine concentration), depending on the measurement.

\section{SENSITIVITY OF DIFFERENT INDICES}

Comparison of TC and PC results for each measurement show that both $s G L$ and $\dot{V} \max _{40 p}$ could detect a response to histamine at a lower concentration than $\mathrm{FEV}_{1}$ (figs 1 and 2).

\section{COMPARISONS BETWEEN PC, TC AND} REACTIVITY

There was a significant correlation between PC results for each measurement ( $\mathrm{r}$ values ranging from 0.73 to 0.95 ) and between TC values for each measurement ( $\mathrm{r}$ values 0.61-0.79) (table 4). Comparison of reactivity results showed lower correlation coefficients and one $\left(r\right.$ sGL-R $\left.\dot{V} \max _{40 \mathrm{p}}\right)$ was not significant. TC and PC results for each measurement correlated significantly, $r$ values varying from 0.63 to 0.91 . Reactivity did not correlate significantly with PC or TC. 
TC

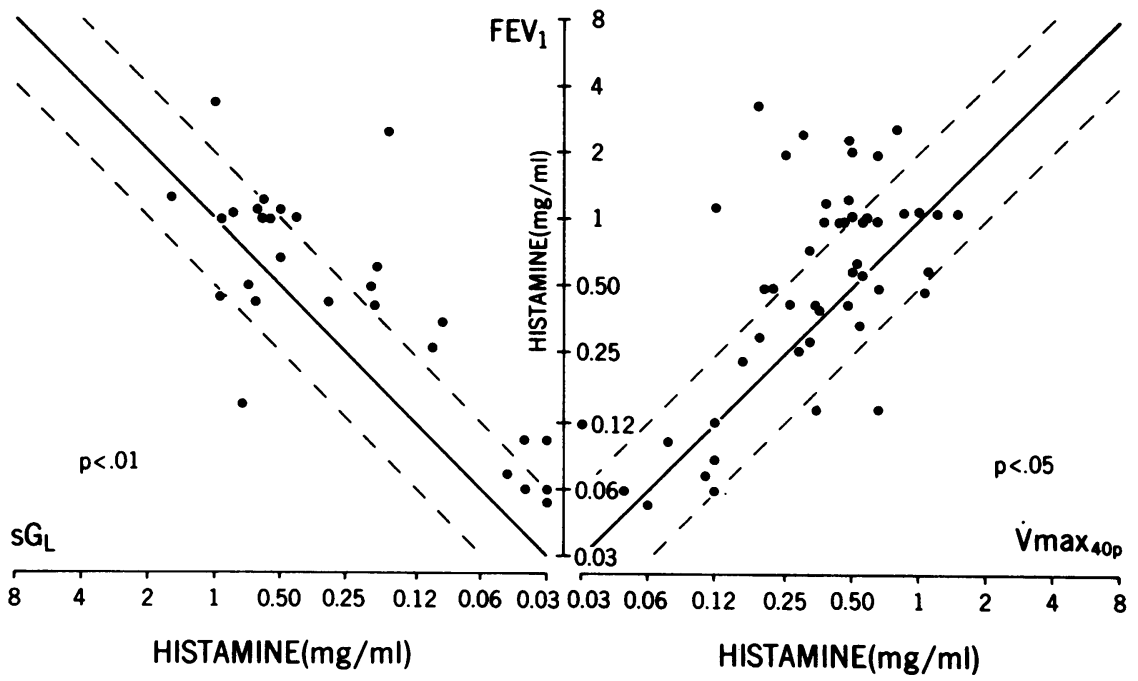

Fig 1 Comparisons of threshold concentration (TC) results obtained at each visit for $F E V_{1}, s G L$, and $\dot{V}_{\max }{ }_{4 \varphi}$. The $T C$ for $s G L$ and $V_{\max }{ }_{4 \varphi}$ detected the response at a lower concentration of histamine than $T C_{F E V_{1}}$ (p values from one-way analysis of variance).

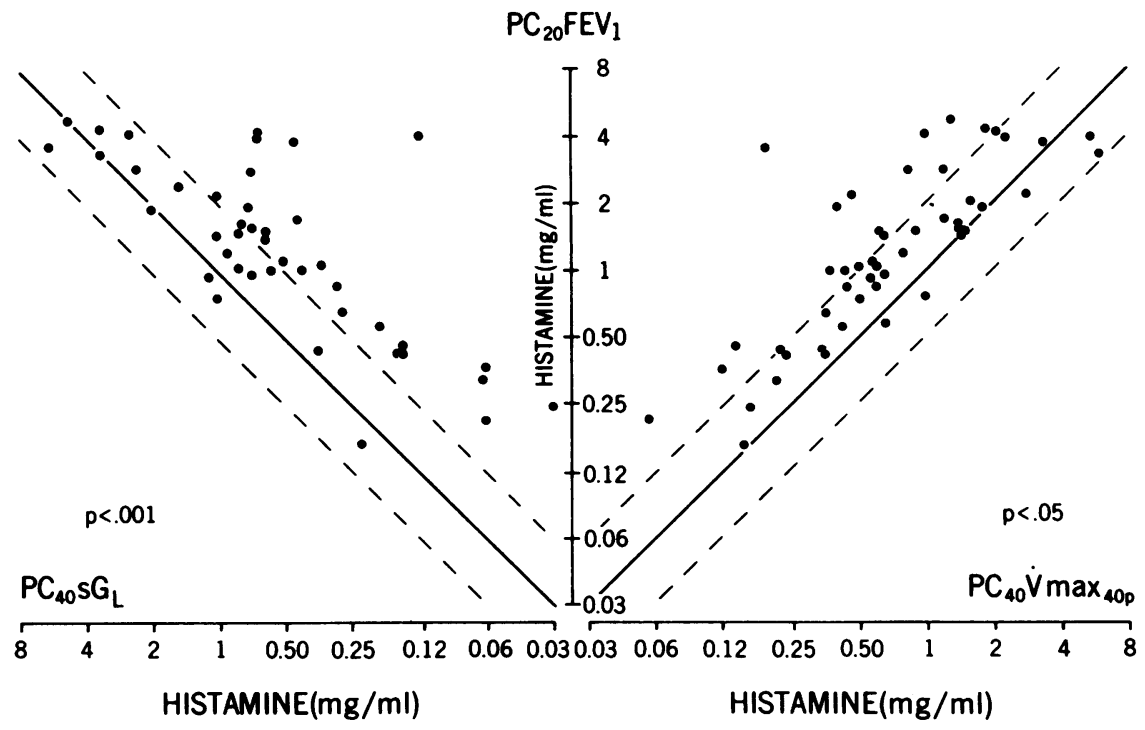

Fig 2 Comparisons of provocative concentration (PC) results obtained at each visit for $F E V_{1}, s G L$, and $\dot{V}_{\max }{ }_{40}$. The $P C_{40}$ for $s G L$ and $V \max _{40 p}$ detected a response at a lower concentration of histamine than $P C_{20-F E V}$. 


\section{Discussion}

In this study we assessed the reproducibility of different ways of measuring bronchoconstriction in response to inhaled histamine. We also evaluated the sensitivity of several indices used to monitor the induced bronchoconstriction. This approach stems from the proposals by Orehek ${ }^{22}$ and other workers that the complete dose-response curves should be studied rather than a single point. The use of measurements other than the FEV, has also been suggested. ${ }^{23-25}$

We found that the concentration of histamine causing a $20 \%$ fall in FEV $\left(\mathrm{PC}_{20}\right)^{6-8}$ was the most reproducible index, a $95 \%$ confidence interval based on a single determination being the observed value \pm 1.59 two-fold concentration difference $( \pm 3.18$ fold difference in $\mathrm{PC}_{20}$ ). This range is larger than that described by Ryan and coworkers. ${ }^{8}$ We used a similar method of nebulisation and baseline FEV varied less than $10 \%$ in both studies. There was a similar difference in reproducibility between two studies from the same group of investigators using a similar method of nebulisation. ${ }^{78}$ The reproducibility of airway hyperreactivity may therefore vary as a result of differences between the subjects studied. As suggested by Ryan and colleagues, ${ }^{8}$ this emphasises the importance of baseline data in studies which examine changes in $\mathrm{PC}_{20-\mathrm{FEV}}$. In our study the reproducibility of $\mathrm{TC}$ was less satisfactory than that of PC.

Some of the theoretical advantages of more complete characterisation of the dose-response curve $^{22}$ are therefore countered by the fact that these measurements are less reproducible than is $\mathrm{PC}$. The $\mathrm{PC}_{20-\mathrm{FEV}}$ has been shown to correlate with the clinical state ${ }^{19}$ and need for medication of asthmatic subjects, ${ }^{26}$ whereas the clinical relevance of reactivity is unknown. Orehek and colleagues claimed that reactivity distinguished normal from asthmatic subjects. ${ }^{26}$ Their dose-response curves, however, were drawn on an arithmetic rather than the more usual scale. In another study using dose-response curves, the reactivity of normal subjects did not differ from that of asthmatic patients. ${ }^{27}$ Beaupré and Malo found no correlation between reactivity and the clinical state of asthma, ${ }^{19}$ while in our study and others ${ }^{1426}$ reactivity correlated with neither PC nor TC. Finally, even if curves assessed by $\mathrm{FEV}_{1}$, sGL, and maximal flows are linear in the range of selected changes, some have found that when assessed in terms of lung resistance they may reach a plateau in some individuals. ${ }^{28}$ This may further complicate their interpretation and use.

One aim of the present work was to assess the sensitivity of different measurements in monitoring induced bronchoconstriction. Bouhuys et al showed that maximum expiratory flow rates detected induced bronchoconstriction at an earlier stage than $\mathrm{FEV}_{1}{ }^{23}$ while Fish and Kelly found that more methacholine was needed to produce a $20 \%$ fall in $\mathrm{FEV}_{1}$ than a $35 \%$ change in specific airway conductance. ${ }^{24}$ Orehek et al showed that $\mathrm{FEV}_{1}$ is less sensitive than airway resistance as a measurement of provoked bronchoconstriction in asthmatic subjects because of the effect of a previous deep inspiration. ${ }^{25}$ Our results are in agreement, since the PC for both $\dot{V}_{\max _{40 p}}$ and $s G_{L}$ detected bronchoconstriction at an earlier stage than did PC $_{20-F E V}$. There might thus be circumstances when the use of an index such as $\mathrm{PC}_{\mathrm{SG}_{\mathrm{L}}}$ is preferable to $\mathrm{PC}_{20-\mathrm{FEV}}$. For example, the $\mathrm{PC}_{30}$ for $\dot{\mathrm{V}} \max _{40 \mathrm{p}}$ but not $\mathrm{PC}_{20-\mathrm{FEV}_{1}}$ separated young symptomless cigarette smokers from non-smokers. ${ }^{29}$ Nevertheless, in most circumstances requiring serial comparisons of airway responsiveness to non-allergic agents for clinical purposes, $\mathrm{PC}_{20-\mathrm{FEV}}$ would seem to be preferable because of its better reproducibility.

Many factors need to be standardised for bronchial provocation tests, ${ }^{29}$ including dose-response curves, which should seek to define the reactions of normal and asthmatic populations in the most satisfactory way, as pointed out by Orehek and Gayrard. ${ }^{30}$ Few such studies have been done. In a study by Cockcroft et al no normal subject had a $\mathrm{PC}_{20-\mathrm{FEV}}$, of less than $8 \mathrm{mg} / \mathrm{ml}$, whereas all the asthmatic patients with symptoms had lower values. ${ }^{6}$ The same group of investigators, ${ }^{31}$ however, recently described a grey zone from 2 to $20 \mathrm{mg} / \mathrm{ml}$ : asthmatic subjects with such responses may have no symptoms, normal diurnal variation of peak flow rate, and no appreciable induced bronchoconstriction unless exposed to a vigorous stimulus. ${ }^{32}$ Orehek et al found that both TC (sensitivity) and reactivity differed between normal and asthmatic subjects, though there was considerable overlap..$^{20}$ In a smaller group of subjects $\mathrm{PC}_{20-\mathrm{FEV}}$ appéared to be more specific than indices using $\mathrm{SGL}$ and maximum partial expiratory flow rates in distinguishing normal from asthmatic responses. ${ }^{32}$ Population studies are needed to evaluate the ability of these various indices to separate normal and asthmatic patients.

This work was supported by a grant from the Canadian Thoracic Society. AR is the recipient of a special summer grant from the Medical Research Council of Canada and RRM is a scholar of the Conseil de la Recherche en Santé du Québec. We want to thank the patients who kindly consented to take part and U Maag and L Senecal for the statistical analysis, as well as FE Hargreave and R Roberts 
(McMaster University) for their helpful criticism. We also wish to express our gratitude to J Normandin for the secretarial work.

\section{References}

${ }^{1}$ Dautrebande L, Philippot E. Crise d'asthme expérimental par aérosols de carbaminoylcholine chez l'homme traitée par dispersat de phénylaminopropane. Etude de l'action sur la respiration de ces substances par la détermination du volume respiratoire utile. Presse Med 1941;49:942-6.

${ }^{2}$ Tiffeneau R, Beauvallet M. Epreuve de bronchoconstriction et de bronchodilatation par aérosols. Emploi pour le dépistage, la mesure et le contrôle des insuffisances respiratoires chroniques. Bull Acad Med Paris 1945;129:165-8.

${ }^{3}$ Curry JJ. The action of histamine on the respiratory tract in normal and asthmatic subjects. $J$ Clin Invest 1946;25:785-91.

${ }^{4}$ De Vries K, Booij-Noord H, Goei JT, Grobler NJ, Sluiter HJ, Tammeling GJ, Orie NGM. Hyperreactivity of the bronchial tree to drugs, chemical and physical agents. In: Orie NGM, Sluiter JH, eds. Bronchitis II. Assen, The Netherlands: Royal VanGorcum, 1964:167.

${ }^{5}$ Chai H, Farr RS, Froehlich LA, et al. Standardization of bronchial inhalation challenge procedures. J Allergy Clin Immunol 1975;56:323-7.

${ }^{6}$ Cockcroft DW, Killian DN, Mellon JJA, Hargreave FE. Bronchial reactivity to inhaled histamine: a method and clinical survey. Clin Allergy 1977;7:235-43.

7 Juniper EF, Frith PA, Dunnett C, Cockcroft DW, Hargreave FE. Reproducibility and comparison of responses to inhaled histamine and methacholine. Thorax 1978;33:705-10.

${ }^{8}$ Ryan G, Dolovich MB, Roberts RS, et al. Standardization of inhalation provocation tests: two techniques of aerosol generation and inhalation compared. Am Rev Respir Dis 1981;123:195-9.

9 Grimaud C, Fondarai J, Aldebert J, Charpin J. Etude de la reproductibilité du test à l'acétylcholine. Poumon Coeur 1967;23:147-53.

${ }^{10}$ Chronic bronchitis, asthma and pulmonary emphysema. A statement by the committee on diagnostic standards for nontuberculous respiratory diseases. $A m R e v$ Respir Dis 1962;85:762-8.

${ }^{11}$ Leith DE, Mead J. Principles of body plethysmograph. In: Procedures for standardized measurements of lung mechanics. Distributed by the division of lung diseases. Bethesda, Maryland: National Heart and Lung Institute, 1974.

12 Mead J, Whittenberger JL. Physical properties of human lungs measured during spontaneous respiration. $J$ Appl Physiol 1953;5:779-96.

${ }^{13}$ Milic-Emili J, Mead J, Turner JM, Glauser EM. Improved techniques for estimating pleural pressure from oesophageal balloons. J Appl Physiol 1964;19:207-11.

${ }^{14}$ Habib MP, Paré PD, Engel LA. Variability of airway responses to inhaled histamine in normal subjects. $J$ Appl Physiol 1979;47:51-8. is Goldman HI, Becklake MR. Respiratory function tests: normal values at median altitudes and the prediction of normal results. American Review of Tuberculosis 1959;79:457-67.

${ }^{16}$ Cherniack RM. Pulmonary function testing. Philadelphia: WB Saundérs, 1977:243.

${ }^{17}$ Cartier A, Bégin P, Sestier M, Malo JL, Martin RR. Time course of the bronchoconstriction induced by inhaled histamine and methacholine in asthmatic subjects. J Appl Physiol 1983;54:821-6.

${ }^{18}$ Orehek J, Kabondo P, Charpín J, Grimaud C. Mesure spirométrique de la réponse bronchique au carbachol dans l'asthme. Bull Europ Physiopath Respir 1978;14:493-502.

${ }^{19}$ Beaupré A, Malo JL. Histamine dose-response curves in asthma: relevance of the distinction between $\mathrm{PC}_{20}$ and reactivity in characterising clinical state. Thorax 1981;36:731-6.

${ }^{20}$ Orehek J, Gayrard P, Smith AP, Grimaud C, Charpin J. Airway response to carbachol in normal and asthmatic subjects. Am Rev Respir Dis 1977;115:937-43.

${ }^{21}$ Eiser NM, MacRea KD, Guz A. Evaluation and expression of bronchial provocation tests. Bull Europ Physiopath Respir 1981;17:427-40.

${ }^{22}$ Orehek J. Relations dose-réponse et tests pharmacologiques de provocation bronchique. Bull Europ Physiopath Respir 1981;17:329-32.

${ }^{23}$ Bouhuys A, Hunt VR, Kim BM, Zapletal A. Maximum expiratory flow rates in induced bronchoconstriction in man. J Clin Invest 1969;48:1159-68.

${ }^{24}$ Fish JE, Kelly JF. Measurements of responsiveness in bronchoprovocation testing. J Allergy Clin Immunol 1979;64:592-6.

${ }^{25}$ Orehek J, Nicoli MM, Delpierre S, Beaupré A. Influence of the previous deep inspiration on the spirometric measurement of provoked bronchoconstriction in asthma. Am Rev Respir Dis 1981;123:269-72.

${ }^{26}$ Juniper EF, Frith PA, Hargreave FE. Airway responsiveness to histamine and methacholine: relationship to minimum treatment to control symptoms of asthma. Thorax 1981;36:575-9.

${ }^{27}$ Hargreave FE, Juniper EF, Ryan G, et al. Clinical significance of nonspecific airway hyperreactivity. In: Hargreave FE. Airway reactivity. Mississauga: Astra, 1980:216-22.

${ }^{28}$ Malo JL, Filiatrault S, Martin RR. Bronchial hyperresponsiveness to inhaled methacholine in young asymptomatic smokers. J Appl Physiol 1982;52:1464-70.

${ }^{29}$ Ryan G, Dolovich MB, Obminski G, et al. Standardization of inhalation provocation tests: influence of nebulizer output, particle size, and method of inhalation. J Allergy Clin Immunol 1981;67:156-61.

${ }^{30}$ Orehek J, Gayrard P. Les tests de provocation bronchique non-spécifiques dans l'asthme. Bull Europ Physiopath Respir 1976;12:565-98.

${ }^{31}$ Hargreave FE, Ryan G, Thomson NC, et al. Bronchial responsiveness to histamine or methacholine in asthma: measurement and clinical significance. $J$ Allergy Clin Immunol 1981;68:347-55.

${ }^{32}$ Michoud MC, Ghezzo H, Amyot R. A comparison of pulmonary function tests used for bronchial challenges. Bull Europ Physiopath Respir 1982;18:60921. 